(C) 1988 ISIJ

|/IIIIIIIIIIIIIIIIIIIII

技術報告

高炉へのオイルコークス・重油スラリーの

|IIIIIIIIIIIIIIIIIIII

均等吹込み

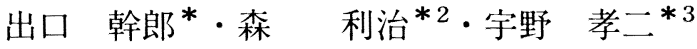 \\ 田中 孝三*4 $*$ 田村 節夫*5
}

\title{
Uniform Injection of Petroleum Coke-Oil Slurry into the Blast Furnace
}

\author{
Mikio DeguchI, Toshiharu MoRI, Kōji Uno, \\ Kōzō TANaKa and Setsuo Tamura
}

\section{Synopsis :}

For the purpose of utilization of the residual oil as a new energy resource for ironmaking, the development of an injecting technique of petroleum coke-oil slurry into a blast furnace was undertaken. In order to establish this technique, the method of uniform injection of the slurry through the tuyeres was studied by the use of the pilot plant with a circulating loop. The petroleum cokes used in this study were the delayed coke and the fluid coke. This development was followed by the demonstration plant test at No. 1 blast furnace of Kobe Works which was provided with the new injection system designed on the basis of pilot plant test results. This slurry injection test through 4 tuyeres was carried out for about 4 months.

As a result, it was confirmed that the continuous injection of $50 \%$ slurry without additives was possible for a long period of time as easily as heavy oil and the errosion of pipelines was not a problem practically. The most important result for blast furnace operation was that the new injection system with a circulating loop made possible a uniform injection of slurry through each tuyere.

Key words : petroleum coke ; slurry ; ironmaking ; blast furnace operation ; injection ; residual oil ; petroleum coke-oil slurry.

\section{1. 緒}

言

高炉の生産性向上と燃料比低減を図るために 1961 年 より安価な重油が吹き込まれていたが，1973 年末の第 一次石油危機によつて重油を節減するための技術開発が 鉄鋼各社で推進された．特に比較的短期間で開発するこ とができ，しかも重油を半隇することができると考えら れた石炭・重油スラリー（COM : Coal Oil Mixture）の 吹込み技術の開発が実施された1) 8).この技術はそれ以 前にも開発されたが，重油を安価に購入することができ たため実用化されなかつた ${ }^{9) 10)}$. 著者らは 1974 年より 沈降防止剤を添加しない COM の高炉吹込み技術の開発 に着手し，1978 年に神戸第 3 高炉で羽口 2 本への吹达 み実験を実施した ${ }^{11) ~ 13)}$. その結果，50\%の COM を 吹き込みうることを確認したが, 羽口 2 本への均等吹込
みやポンプの摩耗などが実用化上の重要な課題として残 つた。 そこで従来の吹込み方式も含めて検討した結果, 各羽口への均等吹达みを達成するための吹込み方式とし て環状管リターン方式を考案した ${ }^{14)}$.

一方，前報 ${ }^{14)}$ に記したように 1979 年 6 月よりオイ ルコークス・重油スラリー（以後スラリーと略称する） の高炉吹込み技術の開発に着手した. 1980 年には環状 管リターン方式を組み込んだパイロットプラントにおい てスラリーの流動特性と吹込み方式の適用性を把握する ための実験を行つた。この実験結果に基づいて設計した 吹込みシステムを神戸第 1 高炬に設置し，1981 年の 8 月から 11 月にかけて約 4 か月間にわたる羽口 4 本への 吹込み実験を行つた ${ }^{15)}$.

従来, 高炉への COM 吹込みにおける課題は, ( 1 )各 羽口への均等吹込み, $(2) \mathrm{COM}$ の製造機器・ポンプ・流

昭和 57 年 4 月. 9 月本会講演大会にて発表 昭和 62 年 9 月 22 日受付 (Received Sep. 22, 1987)

* (株)神戸製鋼所材料研究所 (Materials Research Laboratories, Kobe Steel, Ltd., 1-3-18 Wakinohama-cho Chuo-ku Kobe 651)

*2 (株)神戸製鋼所試作実験センター(Technical Testing \& Development Center, Kobe Steel, Ltd.)

*3 (株)神戸製鋼所石炭液化推進部（現: 日本褐炭液化K.K) (Coal Liquefaction Dept., Kobe Steel, Ltd.,Now Nippon Brown Coal Liquefaction Co., Ltd.)

*4 (株)神戸製鋼所神戸製銅所（Kobe Works, Kobe Steel, Ltd.)

*5 (株)神戸製鋼所鉄銅生産本部生産技術部（現: 第一耐火煉瓦(株)）(Technology Administration Department, Iron \& Steel Production Division, Kobe Steel, Ltd., Now Daiichi Taika Renga Co. Ltd.) 
量調節弁・バーナーなどの摩耗, ( 3 ) COM 中の石炭の 沈降あるいは閉塞などであるとされていた。これらの課 題はスラリーの吹込みにおいても解決しなければならな いものであると考えられる. しかしながらこれらの課題 に対して詳細に報告した例は数少ない7)8).

そこで，本報ではスラリーの製造から吹込みに至るま での各種技術を環状管リターン方式を組み込んだパイ ロットプラントと実炬でのスラリー吹込み実験によつて 検討した結果について報告する.

\section{2. スラリーの吹込み方式の検討}

\section{$2 \cdot 1$ 従来の COM 吹込み方式}

高炉羽口に補助燃料を吹き込む場合，円周方向におい て均一な軟化融着帯形状を確保する上で各羽口への吹込 み量を均等にすることが必要である. しかしながら $\mathrm{COM}$ の粘度はその濃度の増加に伴つて上昇し， $50 \%$ COM では重油の約 10 倍にもなるため配管内の圧力損 失は非常に大きくなる.さらに配管内での沈降とそれに 伴う閉塞も生じるため, COM の均等吹込みは困難とな る.

これまでに報告された主な吹込み方式にはつぎのよう なものがある.（a)羽口 2 本ごとに 1 台のポンプを設置 して全羽口に COM を吹込む方式9),（b）1台のポンプ で COM を流送して順次各羽口に吹き込み再度 COM を タンクに戻すという方式 ${ }^{16)}$ ，(c) 1 台のポンプで COM を流送してタンクに戻すことなく全羽口に吹き込む方 式1) 6)10)，(d) 1 台のポンプで COM を高炉の近くまで 流送し,その一部をタンクに戻しつつ全羽口に吹き込む

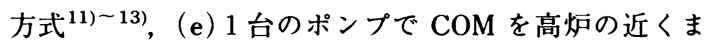
で流送して二分し，その後羽口に吹き込んで再びタンク に戻す方式78) などである.

1978 年に神戸第 3 高炬で実施した羽口 2 本への COM 吹込み実験では (d) と類似の吹込み方式を採用したが, 羽口までの配管の長さが異なつたため, 羽口 2 本への 50\% COM の均等吹込みは困難であつた。 そこで，この 課題を解決すべく新しい吹込み方式として環状管リター ン方式を考案した ${ }^{14)}$. なお本報では COM あるいはス ラリーの濃度を重量百分率(\%)で表す。

\section{$2 \cdot 2$ 環状管リターン方式の特性}

環状管リターン方式のフローチャートの例を神戸第 1 高炉での吹込み実験に使用したもの（Fig. 1) で示す. ここでは，均等吹込みを達成するために必要な条件，す なわちスラリー吹込み時の環状管全長における圧力損失 $\left(\Delta p_{c}: \mathrm{MPa}\right)$ におよほすポンプの吐出量 $\left(Q_{p}: \mathrm{m}^{3} / \mathrm{h}\right)$, 全羽口へのスラリーの吹込み量 $\left(Q_{i}: \mathrm{m}^{3} / \mathrm{h}\right)$, 環状管の

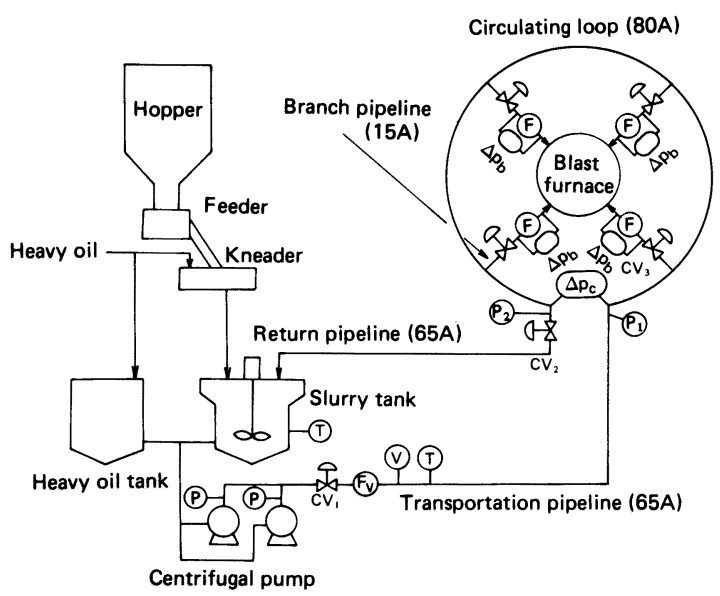

$$
\begin{array}{ll}
\text { CV }: \text { Control Valve } & \mathrm{P}: \text { Pressure gauge } \\
\mathrm{T}: \text { Thermometer } & \mathrm{V}: \text { Viscometer } \\
\mathrm{F}: \text { Ultrasonic flow meter } & \mathrm{F}_{\mathrm{V}}: \text { Venturi meter } \\
\Delta p: \text { Differential pressure gauge }
\end{array}
$$

Fig. 1. Schematic figure of slurry injection system.

内径 $(D: \mathrm{m})$ などの影響を検討する. 配管内の圧力損 失は前報 ${ }^{14)}$ でも述べたようにスラリーをニュートン流 体として取り扱つても良いため, 層流域において成立す る Hagen-Poiseuilleの式によつて計算する.

環状管の入口側から $j$ 番目の羽口に吹き込んだあとの 環状管内の流量と流速をそれぞれ $Q_{j}\left(\mathrm{~m}^{3} / \mathrm{h}\right), v_{j}(\mathrm{~m} / \mathrm{s})$, 全羽口への吹込み量とポンプの吐出量との比 $\left(Q_{p} / Q_{i}\right)$ を $R$, 羽口の本数を $n$ とすると, $Q_{j}, v_{j}, \Delta p_{c}$ はそれぞ れ( 1 ) （ 3 )式で与えられる.

$$
\begin{aligned}
& Q_{J}=\left(R-\frac{j}{n}\right) Q_{i} \\
& v_{j}=\frac{Q_{j}}{900 \pi D^{2}} \\
& \Delta p_{c}=\sum_{j=1}^{n} \frac{32 \mu v_{j} L}{D^{2} n} \times 10^{-6} \\
& =\frac{32 \mu L Q_{i}}{900 \pi D^{4}}\left(R-\frac{1}{2}-\frac{1}{2 n}\right) \times 10^{-6}
\end{aligned}
$$

ここで, $\mu$ はスラリーの粘度 $(\mathrm{Pa} \cdot \mathrm{s}), L$ は環状管の全 長 $(\mathbf{m})$ である.

配管内の流速は沈降の限界流速 $\left(v_{c}: \mathrm{m} / \mathrm{s}\right)$ と摩耗の 限界流速 $\left(v_{a}: \mathrm{m} / \mathrm{s}\right)$ の間に設定する. 沈降の限界流速は (4)式 ${ }^{17)}$ によつて求め, 定数 $K$ は神戸第 3 高炬での COM 吹込み実験結果に基づいて 2.5 とした. すなわち $10 \mathrm{~A}$ の配管（内径: $0.0127 \mathrm{~m}$ ）に対する $v_{c}$ を $0.20 \mathrm{~m} / \mathrm{s}$, 


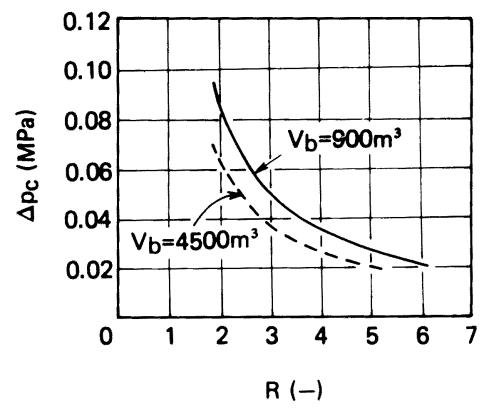

Productivity : $2.0 \mathrm{t} / \mathrm{d}, \mathrm{m}^{3} \quad$ Slurry rate $: 50 \mathrm{~kg} / \mathrm{t}$ $R=$ Discharge rate of slurry by pump/Injection rate through all tuyeres

Fig. 2. Effect of $R$ and blast furnace's volume $\left(v_{b}\right)$ on pressure loss in circulating loop $\left(\Delta p_{c}\right)$.

石炭の比重 $\left(\rho_{c}:-\right)$ を 1.3 , 重油の比重 $\left(\rho_{o}:-\right)$ を 0.9 として $K$ の值を求めた.

$$
v_{c}=K\left\{\left(\frac{\rho_{c}}{\rho_{o}}-1\right) D\right\}^{0.5}
$$

一方，摩耗の限界流速は 3 か月間の使用によつて鋼製 の部品に明らかな摩耗が生じ始めるときの流速を意味 し，本報では神戸第 3 高炉での実験結果より $3.0 \mathrm{~m} / \mathrm{s}$ と定めた。

炉内容積が $900 \mathrm{~m}^{3}$ と $4500 \mathrm{~m}^{3}$ の高炉に対する計算例 （出銑比: $2.0 \mathrm{t} / \mathrm{d}, \mathrm{m}^{3}$, スラリー比: $50 \mathrm{~kg} / \mathrm{t}$ ) を Fig. 2 に示す．環状管の全長はそれぞれ $60 \mathrm{~m}, 120 \mathrm{~m}$ とした。 スラリーの粘度は神戸第 3 高炉での実験で得られた配管 内の压力損失から求めた $50 \% \mathrm{COM}$ の粘度 $(0.134$ $\mathrm{Pa} \cdot \mathrm{s})$ を用いた。 Fig. 2 の結果より $R$ の値かあるいは 炉内容積が大きくなるにつれて環状管全長の圧力損失 $\left(\Delta p_{c}\right)$ が低下寸ることがわかる.なぜなら $R$ かあるい は $Q_{i}$ を大きくする場合には $v_{j}$ を $v_{c}$ と $v_{a}$ の間に設定す るために（1），( 2 )式より $D$ を大きくする必要があり， その值を（ 3 )式に代入するため $\Delta p_{c}$ が $D$ の 4 乗に反比 例して小さくなるからである.

スラリーの均等吹込みを達成するには，神戸第 3 高炉 での COM 吹込み実験結果より環状管全長の圧力損失を 0.04〜0.05 MPa 以下にすれば良いと考えられたため, $R$ の值を約 3 以上にすれば均等吹込みが可能になると 考えられる。

\section{3. パイロットプラントでのスラリー吹込み実験}

\section{$3 \cdot 1$ 設計基準}

環状管リターン方式によるスラリーの均等吹込み実験
はまず前報 ${ }^{14)}$ に示したパイロットプラントで行つた. このプラントはポンプの吐出量を $20 \sim 30 \mathrm{~m}^{3} / \mathrm{h}, \quad 5$ 本の 吹込み管への最大吹込み量を $5 \mathrm{~m}^{3} / \mathrm{h}(R$ の值が $4 \sim 6$ に 相当する）と想定して前節の計算方法に基づいて設計し たものである.実験方法と実験条件は前報と同一であり， オイルコークスにはディレードコークス（DC と略す） とフルードコークス（FCと略す）を用いた。

\section{$3 \cdot 2$ 実験結果}

$0.3 \mathrm{~mm}$ 以下のDC を $40 \%$ 含んだスラリーを 5 本の吹 込み管に吹き込んだ実験からつぎのような結果を得た。

( 1 ) 環状管全長の圧力損失が $0.045 \mathrm{MPa}$ 以下であれば 吹込み管の調節弁を全開にしたままでも 5 本への吹込み 量のばらつきを $\pm 7 \%$ 以下にすることができる.（2) 5 本への吹込み量のばらつきは各吹込み管の調節弁の微 調整によつて無くすることができる．また，（1），（2） の吹込み状態でポンプの直後あるいは環状管出口部の流 量調節弁によつて環状管内の圧力のみを調整することに より 5 本への吹込み量を同時に変更することができ，し かもある吹込み管への吹込みを突発的に停止しても他の 吹込み管への吹込み量が変化しないことも確認した。

以上の結果はオイルコークスの銘柄とその粒度ならび にスラリーの濃度に関係なく得られた。

\section{4. 実炉でのスラリー吹込み実験}

\section{$4 \cdot 1$ 実験方法}

スラリーの吹込み実験の対象となつた高炉は神戸第 1 高炉 (炉内容積: $904 \mathrm{~m}^{3}$, 羽口: 16 本) で吹込み可能な 羽口数は 4 本である. 実験設備のフローチャートを示し たFig. 1 に基づいて実験方法を説明する.

所定の粒度に粉砕されたオイルコークスを $5 \mathrm{~m}^{3}$ の ホッパーに投入し，その後容量式フィーダーによつて所 定量のオイルコークスを 2 軸スクリュー型のニーダーに 供給する.このニーダーに同時に所定量の重油を供給し て,両者を混練することによつてスラリーを製造する(能 力: $2000 \mathrm{~kg} / \mathrm{h}$ ).

ニーダーで製造されたスラリーは $7 \mathrm{~m}^{3}$ のスラリータ ンクに供給され, 所定の温度 $\left(80 \sim 90^{\circ} \mathrm{C}\right)$ に制御される. スラリータンク内にはオイルコークスの沈降を防止する ための攪抖機，スラリーの温度を制御するための水と蒸 気のコイル状配管，スラリーの製造を制御するためのレ ベルスイッチなどが装着されている。 なおスラリータン ク内の機器が故障した場合に備えて重油貯蔵用タンク $\left(5.6 \mathrm{~m}^{3}\right)$ を設置している.

スラリータンクに貯蔵されたスラリーは遠心ポンプ (吐出量: $24 \mathrm{~m}^{3} / \mathrm{h}$, 揚程: $120 \mathrm{~m}$ ) によつて $65 \mathrm{~A}$ の輸送管 
(内径: $0.0659 \mathrm{~m}$ ) から 80A の環状管 (内径: $0.0781 \mathrm{~m}$, 長さ: $58 \mathrm{~m}$ ) と $65 \mathrm{~A}$ のリターン配管を経由して再びスラ リータンクに戻される。このメインラインの全長は約 $300 \mathrm{~m}$ である. ポンプの吐出量と環状管内の圧力はポン プ直後と環状管出口部に設置された流量調節弁 $\left(\mathrm{CV}_{1}\right.$ と $\left.\mathrm{CV}_{2}\right)$ によつて調整される.

ポンプの吐出量は差圧式流量計と超音波式ドップラー 流量計, 配管内の圧力と圧力損失はダイヤフラム式の圧 力計と差圧計, 温度は熱電対, 粘度はねじれ振動式粘度 計によつてそれぞれ測定される.

スラリーは環状管から分岐した $15 \mathrm{~A}$ の吹込み管（内 径: $0.0161 \mathrm{~m}$, 長さ: $6 \mathrm{~m}$ ) を通して 4 本の羽口に吹き込 まれる，吹込み量の調整はパイロットプラントでの実験 と同様であり, 粗調整は $\mathrm{CV}_{1}$ と $\mathrm{CV}_{2}$ による環状管内 の圧力調整で, 微調整は吹込み管に設置した調節弁 $\left(\mathrm{CV}_{3}\right)$ でそれぞれ行う。その吹込み量は吹込み管に設 置した超音波式ドップラー流量計と差圧計によつて測定 される.バーナーには重油吹込み用バーナーを用い, そ のノズル径は $3 \sim 5 \mathrm{~mm}$ である。また，スラリーを吹き 込む 4 本のブローパイプには送風圧を測定するための圧 力計も設置されている. なお，スラリーの吹込み羽口以 外には補助燃料を吹き込んでいないため, スラリーの吹 込み量の増減に対応してコークスの装入量を変更する.

\section{$4 \cdot 2$ 実験条件}

実験に使用したオイルコークスと重油の組成は前

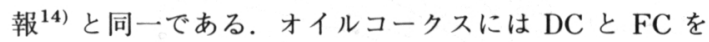
用い, その粒度は Table 1 に示すように DC が 2 種類, $\mathrm{FC}$ が 1 種類である. $0.15 \mathrm{~mm}$ 以下の $\mathrm{DC}$ スラリーを $\mathrm{A}$ スラリー, $0.30 \mathrm{~mm}$ 以下の $\mathrm{DC}$ スラリーを $\mathrm{B}$ スリリー, $0.30 \mathrm{~mm}$ 以下の FC スラリーをCスラリーとそれぞれ

Table 1. Particle size of petroleum coke and denomination of slurry.

\begin{tabular}{|c|c|c|c|c|}
\hline Species & $\underset{(\mathrm{mm})}{\text { Max. dia. }}$ & 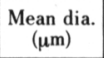 & $\begin{array}{c}-74 \mu \mathrm{m} \\
(\%)\end{array}$ & $\begin{array}{c}\text { Denomination } \\
\text { of slurry }\end{array}$ \\
\hline Delayed coke (DC) & $\begin{array}{l}0.15 \\
0.30\end{array}$ & $\begin{array}{l}44 \\
82\end{array}$ & $\begin{array}{l}63 \\
45\end{array}$ & $\begin{array}{l}\text { Slurry A } \\
\text { Slurry B }\end{array}$ \\
\hline Fluid coke $\quad(\mathrm{FC})$ & 0.30 & 68 & 51 & Slurry C \\
\hline
\end{tabular}

Table 2. Experimental progress of slurry injection test into blast furnace.

\begin{tabular}{c|l}
\hline Period & Injectant \\
\hline 3rd Aug. 16th Aug. & Heavy oil \\
17th Aug. 13th Sep. & Slurry B \\
14th Sep. 13th Oct. & Slurry A \\
14th Oct. 24th Oct. & Slurry C \\
25th Oct. $~$ 8th Nov. & Heavy oil \\
9th Nov. 16th Nov. & Slurry A \\
17th Nov. 25th Nov. & Slurry C \\
\hline
\end{tabular}

\section{略記する.}

スラリーの吹込み条件は，濃度が 0 〜 $50 \%$, 温度が $80 \sim 90^{\circ} \mathrm{C}$, 吹込み羽口数が 1 4 本, 吹込み量が 100 $200 \mathrm{~kg} / \mathrm{h}$, tuy. であり, ポンプの吐出量は $20 \sim 25 \mathrm{~m}^{3} / \mathrm{h}$ であつた。したがつて $200 \mathrm{~kg} / \mathrm{h}$, tuy. 吹込み時の $R$ の 值は $6 〜 8$ に相当する.

実験期間中における高炉操業条件は平均値で, 送風量 が $1338 \mathrm{Nm}^{3} / \mathrm{min}$, 送風温度が $844^{\circ} \mathrm{C}$, 送風圧力が $0.0987 \mathrm{MPa}$ ，出銑量が $1380 \mathrm{t} / \mathrm{d}$ であつた.

\section{$4 \cdot 3$ 実験結果および考察}

\section{$4 \cdot 3 \cdot 1$ 吹込み実績}

Table 2 に示すような日程でスラリーの吹込み実験を 約 4 か月間にわたつて実施した結果, 沈降防止剂を添加 しなくともオイルコークスの銘柄や粒度に関係なく $50 \%$ スラリーを重油とほとんど同じように吹き込むこ とができた。実験期間中に吹込みを停止したのは流量調 節弁 $\left(\mathrm{CV}_{1}\right)$ の摩耗状態を調査したためであり，わずか $14 \mathrm{~h}$ 停止しただけであつた。稼働率で表すと $99.4 \%$ に 達する。

$4 \cdot 3 \cdot 2$ スラリーの製造技術

ニーダーによるスラリーの製造は $50 \%$ の濃度まで行 うことができ，しかも Photo. 1 に示すように約 4 か月 間にわたつて使用した後でもほとんど摩耗せずその耐久 性を確認することができた。

\section{$4 \cdot 3 \cdot 3$ スラリーの貯蔵技術}

スラリーの粘度は前報 ${ }^{14)}$ でも報告したように温度の 影響を非常に強く受けるため，スラリーの吹込み技術を 開発する上でスラリータンク内の温度制御を精密に行う ことが不可欠である. スラリータンク内の温度はコイル 状配管への水と蒸気の供給量を調節することによつて設 定值に対して常に土0.2 ${ }^{\circ} \mathrm{C}$ 以下に制御することができ た.

一方, スラリータンク内でのオイルコークスの沈降は

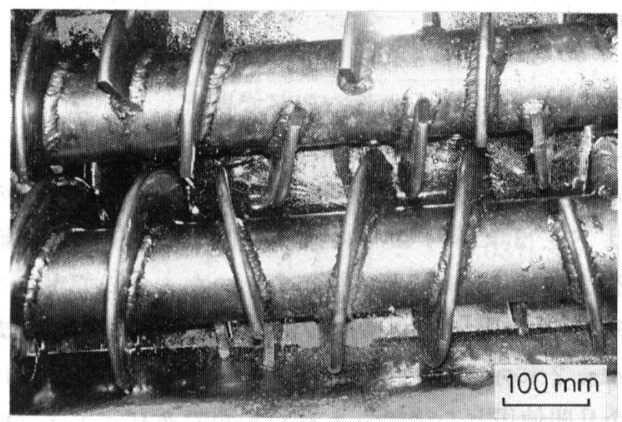

Photo. 1. Screw of kneader used for 4 months. 


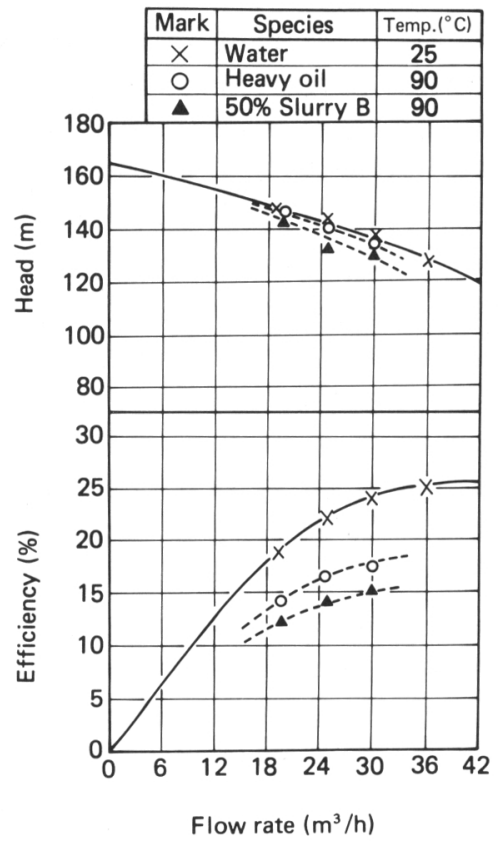

Fig. 3. Effect of slurry concentration on pump efficiency and head.

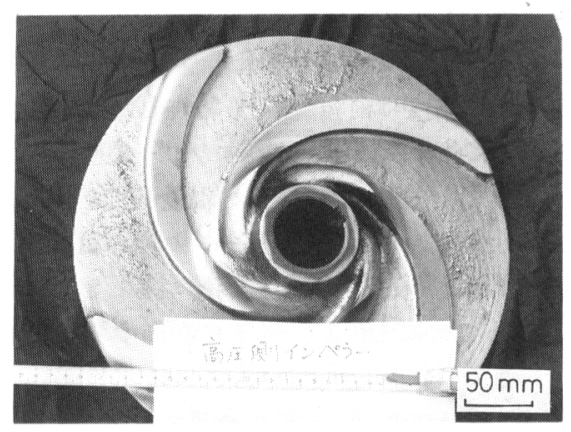

Photo. 2. Impeller of centrifugal pump used for 4 months.

攪拌機によつて防止することができた.

\section{$4 \cdot 3 \cdot 4$ スラリーの流送技術}

$50 \%$ の B スラリーを流送しているときのポンプの効 率はFig. 3 に示すように水流送時よりも約 $10 \%$ 低下 するが，実用上の問題は皆無であつた。ここでポンプの 効率は（吐出圧 $\times$ 吐出量/軸動力）で表せる。また Photo. 2 に示すようにポンプのインペラーの摩耗は約 4 か月間使用した後でさえもわずかであり，ポンプの効 率も約 $1 \%$ 低下した程度であつた。したがつて長期間

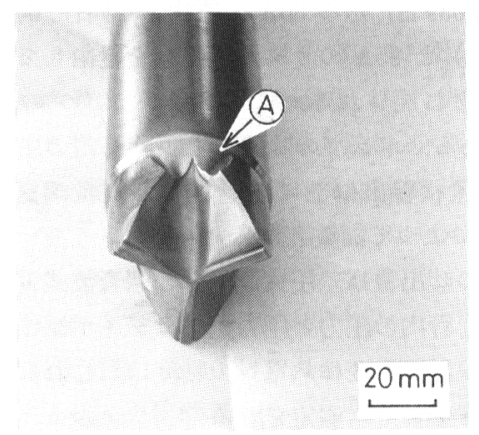

A: Eroded part

Photo. 3. Plug of pressure control valve used for 3 months.

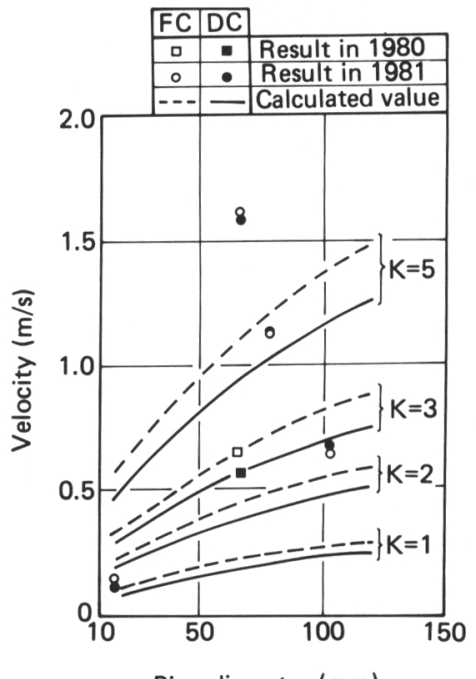

Pipe diameter $(\mathrm{mm})$

Fig. 4. Relation between actual velocity in pipeline and critical velocity calculated by Smoldirev's equation.

にわたるスラリーの安定流送に対する遠心ポンプの実用 性を確認することができた。

Photo. 3 には 3 か月間使用した後の流量調節弁（Fig. 1 の $\left.\mathrm{CV}_{1}\right)$ のプラグの摩耗状態を示す。摩耗した部分は スラリーの通過流速が高い部分に相当する。この程度摩 耗しても制御性に問題がなかつたため，3 か月ごとに摩 耗した部品を交換すれば良いものも考えられる.

配管内でのオイルコークスの沈降は(4)式において定 数 $K$ を 2.5 としたときの限界流速以上で流送すること によつて防止しようと考えたが，沈降しやすい $\mathrm{FC}^{14)}$ でさえもさらに低流速にしても安定して流送することが 
できた。そこで，パイロットプラントと実炉での実験に おける各配管内の流速の最小値を(4)式による計算値と 比較した結果を Fig. 4 に示す.

図中の実線と破線はそれぞれ DC と FC の限界流速を (4)式によつて計算した值である。実験では配管径が $16.1 \mathrm{~mm}$ の吹込み管の場合だけ限界流速に近い状態に したが，その他の配管に対しては意図的に流速を下げる ことはしなかつた。したがつて沈降の限界流速は安全性 を考慮して $K$ の值を 2 としたときの流速を採用すれば 沈降を生じることなく流送できるものと考えられる.

$4 \cdot 3 \cdot 5$ スラリーの流送特性

Fig. 5 には環状管におけるスラリーの圧力損失にお よぼすスラリーの濃度と銘柄の影響を示す．流量は 20 $\mathrm{m}^{3} / \mathrm{h}$, 温度は $90^{\circ} \mathrm{C}$ の場合である. 前報 ${ }^{14)}$ と同様, $B$ スラリーの圧力損失は濃度の増加と共に増大し， $50 \%$ スラリーの圧力損失は重油の約 3.7 倍になつているこ とがわかる. 一方， $50 \%$ の A スラリーの圧力損失は $\mathrm{B}$ スラリーのそれよりも大きいが，これは DCの粒度が 小さいからである。また，前報 ${ }^{14)}$ で述べたように DC と FC の粒度が同一であれば B スラリーの圧力損失が Cスラリーのそれよりも大きくなるはずであるが，本実 験では Bスラリーと C スラリーの圧力損失がほぼ同じ值 となった。これは Table 1 に示すようにDCの平均粒 径よりも FC の方が細かいためであると考えられる。

前報 ${ }^{14)}$ で述べたようにスラリーをニュートン流体と 見なしても良いため，これらの値を Hagen-Poiseuille

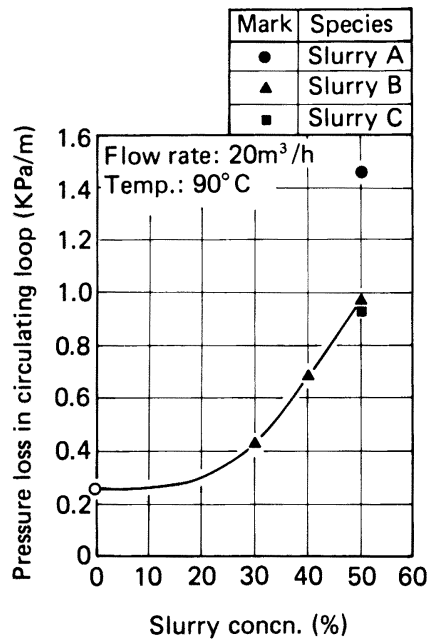

Fig. 5. Effect of slurry concentration and slurry species on pressure loss in circulating loop (I.D. : $78.1 \mathrm{~mm}$ ).
の式に代入してスラリーの粘度を求めた。 その計算値と 配管に設置したねじれ振動式粘度計による測定值の関係 を Fig. 6 に示す。両者には良好な相関性があり，ねじ れ振動式粘度計の実用性を確認することができた。なお 配管に設置した流量計や圧力計は実験期間中正常に作動 し，その実用性を確認した。

\section{$4 \cdot 3 \cdot 6$ スラリーの吹込み技術}

Fig. 7 には各吹込み管の流量調節弁の開度を調整し てスラリーを吹き込んだときの各羽口への分配状況を示 す. 羽口の番号は環状管の入口側から順に $6,3,14$, 10 となつており， $\Delta p_{b}$ は吹込み管の圧力損失 $(\mathrm{MPa})$ を意味する。スラリーの温度は $90^{\circ} \mathrm{C}$, 吹込み量は 200 $\mathrm{kg} / \mathrm{h}$ の場合である.この図において環状管の圧力損失

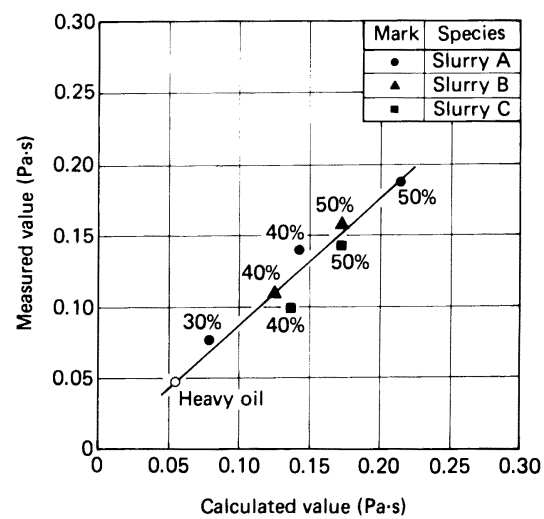

Fig. 6. Relation between viscosity measured by viscometer and viscosity calculated by HagenPoiseuille's equation.

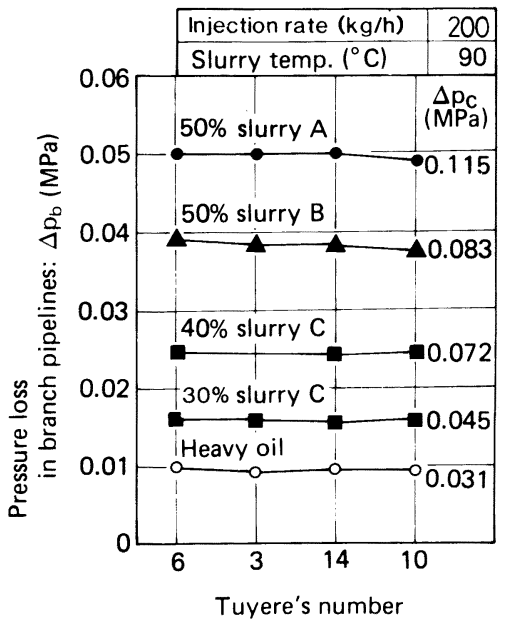

Fig. 7. Degree of slurry distribution among four tuyeres. 


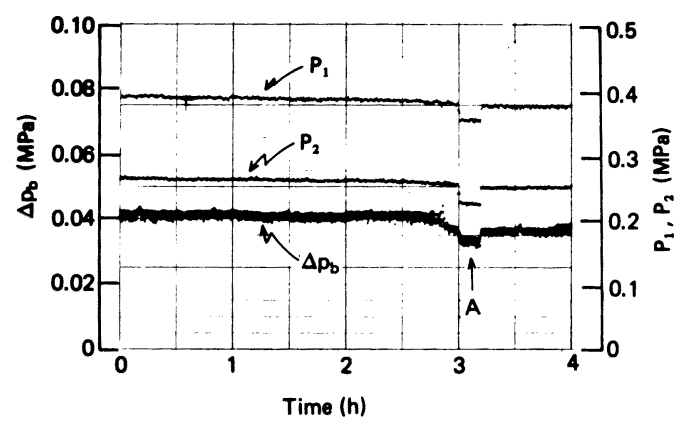

$p_{1}, p_{2}$ : Pressure at the inlet and outlet of circulating loop $\Delta p_{b}$ : Pressure loss in branch pipelines

Fig. 8. Change in injection rate through four tuyeres.

$\left(\Delta p_{c}\right)$ が増大して $0.115 \mathrm{MPa}$ になっても， 4 本の吹込 み管の圧力損失 $\left(\Delta p_{b}\right)$ のばらつきは $2 \%$ 以内である ことがわかる.この場合圧力損失はスラリー流量に比例 するので, 羽口 4 本への吹込み量のばらつきが $\pm 2 \%$ 以内であることに相当する. 次に吹达み量の時間的な変 化の一例を Fig. 8 に示す。これは $50 \%$ のB スラリー を 4 本の羽口に吹き込んでいるときのチャートである. $p_{1}$ と $p_{2}$ は環状管の入口と出口の圧力（ $\mathrm{MPa}$ )を意味す る.この図より，4 本の吹込み管の圧力損失のばらつき, すなわち羽口 4 本への吹込み量のばらつきが $\pm 5 \%$ 以 内であることがわかる．また，それぞれの流量調節弁の 開度を一度設定すれば長時間にわたつて再調整しなくて も良いこともわかる．さらにA点では環状管出口部の流 量調節弁 $\left(\mathrm{CV}_{2}\right)$ の開度のみを大きくして環状管内の圧 力を下げたが, 各羽口への均等吹込みを確保したままで 羽口 4 本への吹込み量を同時に下げることができた。 そ の後再び元の状態に戻すこともできている．このように 環状管出口部あるいはポンプ直後の流量調節弁の開度を 調整して環状管内の圧力を変更することにより，均等吹 込みを確保したままで羽口 4 本への吹込み量を同時に変 更しうることを確認した。

Fig. 9 は羽口 4 本に $50 \%$ のB スラリーを吹き込んで いる場合にB点で 1 本だけ吹込みを停止したときの チャートである，吹込みを停止して再び吹き込んでいる ため吹込み管の圧力損失を示す点が変動しているが，そ の他の点は一定值のままである。これは環状管を流れて いるスラリーの流量が羽口への吹込み量の約 100 倍と なつているためである.

Fig. 10 には 50\% のCスラリーを 1 本の羽口に吹き込 んでいるときの吹込み量におよぼす送風圧 $\left(P_{B}: \mathrm{MPa}\right)$

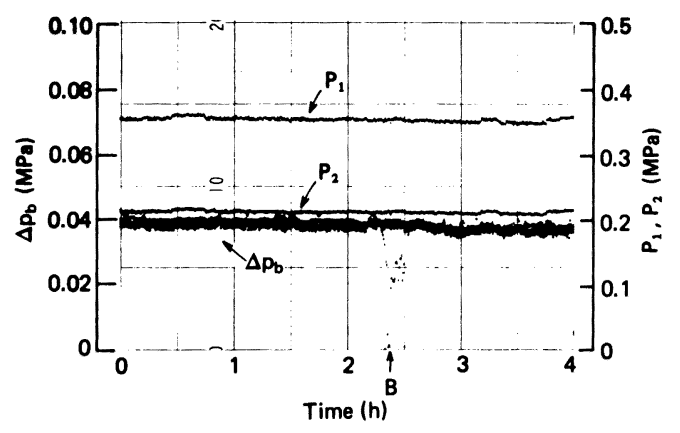

$p_{1}, p_{2}$ : Pressure at the inlet and outlet of circulating loop $\Delta p_{b}$ : Pressure loss in branch pipelines

Fig. 9. Change in injection rate through four tuyeres.

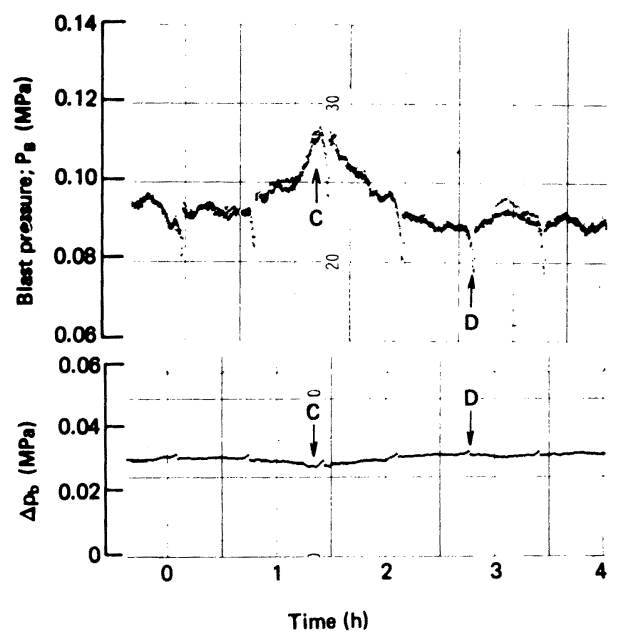

$\Delta p_{b}:$ Pressure loss in branch pipelines

Fig. 10. Effect of blast pressure on the slurry injection rate.

の影響を示す。この図より送風圧の変動に伴つてスラ リーの吹込み量がわずかに変化していることがわかる. すなわち，C点では送風圧が上昇したために吹込み量が 滅少し，D点では熱風炉の切替えに伴う送風圧の低下に よつて吹込み量が増加している，そこでスラリーの吹込 み量 $\left(q_{i}: \mathrm{kg} / \mathrm{h}\right)$ におよぼすバーナー内の圧力と送風压 の差,つまりバーナーのノズルでの圧力損失 $\left(\Delta p_{i}: \mathrm{MPa}\right)$ の影響をパイロットプラントでの実験結果も含めて検討 すると，Fig. 11 に示すように $q_{i}$ が $\Delta p_{i}$ の約 0.5 乗に 比例することがわかる。 これは $\Delta p_{i}$ がスラリ一噴出時 の運動エネルギーに比例すると考えられるからである. また, Fig. 11 から $0.01 \mathrm{MPa}$ 送風圧変動に伴つてス 


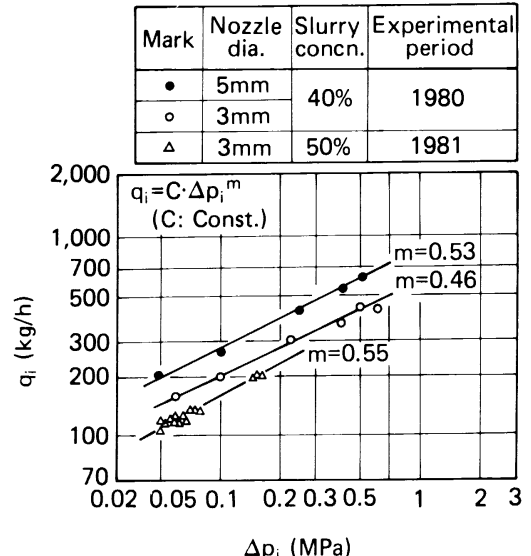

Fig. 11. Relation between injection rate $\left(q_{i}\right)$ and pressure loss in burner nozzle $\left(\Delta p_{i}\right)$.

ラリーの吹込み量が約 $8 \mathrm{~kg} / \mathrm{h}$ 変動することもわかる. この変動量を小さくするには環状管内の圧力と送風圧の 差が一定となるように環状管出口部の流量調節弁の開度 を自動制御すれば良いと考えられる。

バーナーのノズルでの閉塞はオイルコークスの最大粒 径を確実に管理することによつて完全に防止することが できた。一方，ノズルの摩耗は C スラリー吹込み時にの み生じ，6 日間の吹込みでノズル径が約 1.5 倍となつ た。これは前報14) で述べたように FCの粉砕性が悪い ことに対応する.

\section{5. 結言}

オイルコークス・重油スラリーの高炉吹込み技術を開 発するために，環状管リターン方式を組み込んだパイ ロットプラントで羽ロへの均等吹込みのための実験を行 つた.オイルコークスにはディレードコークスとフルー ドコークスを用いた。続いてその実験結果に基づいて設 計・製作した吹込みシステムを神戸第 1 高炉に設置して 約 4 か月間にわたる羽口 4 本へのスラリー吹込み実験を 実施した。

その結果，スラリー中に沈降防止㓱を添加しなくとも $50 \%$ のスラリーを従来の重油吹込みとほとんど同じよ うに長期間にわたつて吹き込むことができ，しかも配管
系統内の摩耗も実用上問題にならないことを確認した。 つまり，今回採用したスラリーの製造プロセスにおける ニーダー，貯蔵プロセスにおける温度制御方式，流送プ ロセスに扔ける遠心ポンプ，吹込みプロセスにおける環 状管リ夕ーン方式などの各要素技術ならびに本システム 全体が高炉操業に適しており，しかも信頼性の高いもの であるということが明確になつた，中でも特に環状管り ターン方式の採用によつて高炉操業上重要な各羽口への 均等吹込みを容易に精度良く行いうることが実証でき た。

\section{文献}

1 ）一宮正俊，木村光蔵，大森英明，相馬克已，荒谷復夫: 鉄と鋼，66（1980), S 646

2 ) 安藤博文, 荒谷復夫, 一宮正俊, 木村光蔵, 大森英明, 相馬克巳: 川崎製鉄技報，14（1982），p. 145

3 ) $S$. Yabe, $I$. Kurashige, $T$. Miyazaki, $T$. Iba, $M$. KoJima, $Y$. SHOJI and Y. KamEI: Proc. 40th Ironmaking Conference, 40 (1981), p. 468

4 ) 射場 毅, 小島正光, 網永洋一，山本章生，藤沢三郎: 住友金属，34（1982），p. 482

5 ) 久光脩文，東海林泰夫，福田 匡: 住友金属，34（1982）, p. 496

6 ）矢部茂慶, 小島正光, 宮崎富夫, 東海林泰夫, 倉重一郎, 射場 毅: 鉄と銅，68（1982），A9

7 ) N. H. Keyser, $V$. D. Beaucaire and $L$. A. Marlin: Proc. 39th Ironmaking Conference, 39 (1980), p. 50

8 ) A. Mertdogan, $L . A$. Marlin, $V$. D. Beaucaire and $S . G$. JANSTO: Proc. 42th Ironmaking Conference, 42 (1983), p. 593

9 ）森永孝三, 田島喜久雄, 楠野桂三, 城本義光, 金山有治, 松岡 宏: 鉄と鋼, 52（1966）, p. 107

10）菊地敏治, 長井 保, 岡部侠児, 矢崎三郎, 後藤公平, 才野光男: 鉄と鋼，53（1967），S193

11) 成田貴一, 前川昌大, 出口幹郎, 八谷 晋, 吉岡邦宏, 田村節夫，松原 格，布施 憲: 鉄と鋼，65（1979）， $\mathrm{S} 46$

12）成田貴一, 前川昌大, 出门幹郎, 森 利治, 永井親久, 八谷 晋, 加藤健三，田村節夫: 鉄と鋼, 65 (1979), $\mathrm{S} 47$

13) $K$. Narita, $M$. Maekawa, $M$. Deguchi, $C$. Nagal and $S$. TAmURA: International Blast Furnace Hearth and Raceway Symposium, Newcastle (1981), p. 8-1

14 ）出口幹郎, 笹原茂樹, 葛西丈次, 田中孝三, 田村節夫: 鉄と鋼，73 (1987), p. 1972

15）出口幹郎，佐藤健一，宇野孝二，田村節夫：神戸製鎆技報， 33 (1983) 3, p. 81

16) V. K. Kornev, A. S. Fofanov, B. L. Lazarev, Yu. S. Borisov, A. E. Parenkov, B. D. Yantsen and $N . F$. FroLov: Stal in English (1967), p. 279

17) 寺田進: 固体混合液の管路輸送 (1973), p. 102 [理工図書] 